\title{
Effect of polyphenols supplemented canola meal based diet on growth performance, nutrient digestibility and antioxidant activity of common carp (Cyprinus carpio Linnaeus, 1758) fingerlings
}

\author{
SYED MAKHDOOM HUSSAIN ${ }^{1}$, HINA GOHAR ${ }^{1}$, AZHAR RASUL ${ }^{1}$, MUHAMMAD \\ MUDASSAR SHAHZAD ${ }^{2}$, AFIA MUHAMMAD AKRAM², MUHAMMAD TARIQ ${ }^{2}$, \\ MAJID HUSSAIN ${ }^{3}$, MUKHTIAR ALI $^{1}$ AND ANAM KHALID ${ }^{4}$ \\ ${ }^{1}$ Fish Nutrition Lab, Department of Zoology, Government College University, Faisalabad, Pakistan \\ ${ }^{2}$ Department of Zoology, Division of Science and Technology, University of Education Township, Lahore, Pakistan \\ ${ }^{3}$ Department of Zoology, University of Okara, Okara, Pakistan \\ ${ }^{4}$ College of Fisheries and Life Sciences, Shanghai Ocean University, China \\ e-mail:drmakhdoom90@gmail.com
}

\begin{abstract}
A 70-days feeding trial was conducted to assess the impact of polyphenols supplemented canola meal based diets on growth performance, nutrient digestibility and antioxidant activity of common carp (Cyprinus carpio Linnaeus, 1758) fingerlings. Seven experimental diets viz., T0, T1, T2, T3, T4, T5, T6 and T7 with graded levels of polyphenols at 0, 100, 200, 300, 400,500 and $600 \mathrm{mg} \mathrm{kg}^{-1}$ respectively were formulated. Each treatment diet was fed to fishes in triplicate tanks and in each replicate, fifteen fingerlings were stocked. Effect of each treatment on the weight gain, feed conversion ratio (FCR), specific grwth rate (SGR), nutrient digestibility and antioxidant activity were assessed. Maximum growth performance, highest SGR (1.41) and best FCR (1.31) was observed in fish fed test diet T4 having $400 \mathrm{mg} \mathrm{kg}^{-1}$ of polyphenols. Nutrient digestibility in terms of crude protein $(72 \%)$, crude fat $(76 \%)$ and gross energy $(67 \%)$ also significantly increased $(p<0.05)$ by supplementation of polyphenols at $400 \mathrm{mg} \mathrm{kg}^{-1}$ level. With respect to antioxidant activity, increasing trend was observed with increasing levels of dietary polyphenols with the highest antioxidant activity recorded in fish fed T6 diet supplemented with $600 \mathrm{mg} \mathrm{kg}^{-1}$ of polyphenols.
\end{abstract}

Keywords: Common carp, Lipid oxidation, Nutrients digestibility, Phenolic compounds, Weight gain

\section{Introduction}

Feed, a major input in aquaculture production, is a fundamental challenge hindering the development and growth of aquaculture sector (Gabriel et al., 2007). Aquaculture feed mainly relies upon the utilisation of fishmeal because of its high palatability and nutritious esteem (NRC, 2011). In fish feed, replacement of fish meal with ingredients which are less costly and are plant or animal derived, is essential as a result of growing cost and unpredictable availability of fish meal (Mahboob, 2014). Canola meal (CM), having highly digestible protein content (38\%), is an appropriate alternative to fish meal. It has the best amino acid balance than all other currently accessible commercial sources of protein from plants (Enami, 2011). In comparison with soybean meal and fish meal, canola meal is reported to be more economical (Hussain et al., 2015).

Antioxidative status of fish needs to be necessarily improved with the increase in water pollution and its stimulating consequences on oxidative stress. Accordingly, any push to support this framework might be related with useful impacts on wellbeing of fish (Gabor et al., 2012). Fish is susceptible to peroxidation of n-3 polyunsaturated fatty acids (PUFA) which results in restriction of storage and processing possibilities (Sampels, 2013). So, as a result of oxidation in body of fish, there is great risk of loss in its quality (Medina et al., 2009). Lipid oxidation contributes to harmful consequences, leading to off flavour and rancid taste as well as formation of various substances which have unfavourable impacts on human wellbeing (Sampels, 2013). Therefore, in order to increase the storage stability and nutritional value of farmed fish (Kazimierczak et al., 2008), inclusion of antioxidants in fish feed is essential. Antioxidants scavenge free radicals and have health promoting effects (Biglari et al., 2008). Polyphenols exhibit antibacterial, antioxidant and antiinflammatory properties which protect the fish against disease and oxidative stress (Kamatou et al., 2010; Samec et al., 2010). Plant parts exhibit high antioxidant capacity especially because of phenolic contents i.e. anthocyanins and ascorbic acid, which play the role of radical scavengers 
and inhibit oxidation. For the most part, the antioxidant activity of vegetables as well as fruits increases with the increase in concentration of total phenolics and flavonoids (Ghasemi et al., 2009).

Common carp (Cyprinus carpio Linnaeus, 1758), is one of the important farmed species around the world contributing significantly to aquaculture production of many countries (Rechulicz et al., 2014). It is a bottom feeder and relies on benthic organisms as well as decaying matter for its nutritional requirements (Khan et al., 2016). The objective of the present study was to check the effect of canola meal based diets supplemented with polyphenols on growth performance, nutrients digestibility and antioxidant activity in C. carpio fingerlings.

\section{Materials and methods}

The experimental trial was conducted in the Fish Nutrition Laboratory, Department of Zoology, Government College University, Faisalabad, Pakistan.

\section{Experimental set up}

For experimental work, C. carpio fingerlings were procured from the Government Fish Seed Hatchery, Faisalabad and were stocked in indoor water tanks having 701 water holding capacity and made of steel, specially designed for faecal collection. Fingerlings were acclimatised to the experimental conditions for 15 days and were fed on basal diet @4\% body weight twice daily (Allan and Rowland, 1992). During the experimental period, water quality parameters particularly, temperature, dissolved oxygen and $\mathrm{pH}$ were monitored regularly which ranged from $24.9-28.7^{\circ} \mathrm{C}, 5.8-7.3 \mathrm{mg} \mathrm{l}^{-1}$ and 7.4-8.6, respectively. Aeration was provided round the clock in all the experimental tanks. Prior to initiation of the experiment, the fish fingerlings were given immersion treatment in $0.5 \%$ saline solution for 1 to $2 \mathrm{~min}$ to kill any ectoparasites (if present) (Rowland and Ingram, 1991).

\section{Experimental design}

Experimental diets were divided into one control and six test diets. Seven canola meal (CM) based diets viz., T0, T1, T2, T3, T4, T5, T6 and T7 were prepared supplemented with graded levels of 0,100 , 200, 300, 400, 500 and $600 \mathrm{mg} \mathrm{kg}^{-1}$ respectively of polyphenols (Total phenols, Flavonols, Anthocyanins, and Phenylpropanoids collected from cabbage). Triplicate tanks were used for each treatment and each replicate had 15 fingerlings each. The experimental trial was conducted following a completely randomised design (CRD) for a period of 70 days. C. carpio fingerlings fed with test diets were compared with control as well as between test groups to assess growth performance, antioxidant activity and nutrient digestibility parameters.

\section{Feed ingredients and formulation of experimental diets}

Polyphenols were procured from the Natural Product and Synthetic Chemistry Lab, Department of Applied Chemistry and Biochemistry, Government College University, Faisalabad. Other feed ingredients were purchased from a commercial feed mill and were analysed for chemical composition following AOAC (1995) prior to formulation of the experimental diet (Table 1). Proximate composition of the feed ingredients are given in Table 2. The feed ingredients were finely ground and sieved through a $0.5 \mathrm{~mm}$ mesh size sieve. All ingredients were mixed in an electric mixer for $10 \mathrm{~min}$ and fish oil was gradually added. During mixing of ingredients $15 \%$ water was also added to prepare a dough (Lovell, 1989). Then, these mixed feed ingredients were extruded through a lab

Table 1. Ingredients and proximate composition (\%) of test diets

\begin{tabular}{|c|c|c|c|c|c|c|c|}
\hline \multirow{3}{*}{ Ingredients } & Control Diet (T0) & Test diet T1 & Test diet T2 & Test diet T3 & Test diet T4 & Test diet T5 & Test diet t6 \\
\hline & \multicolumn{6}{|c|}{ Polyphenols $\left(\mathrm{mg} \mathrm{kg}^{-1}\right)$} & \\
\hline & 0 & 100 & 200 & 300 & 400 & 500 & 600 \\
\hline Canola meal & 55 & 55 & 55 & 55 & 55 & 55 & 55 \\
\hline Fish meal & 16 & 16 & 16 & 16 & 16 & 16 & 16 \\
\hline Wheat flour* & 11 & 10.9 & 10.8 & 10.7 & 10.6 & 10.5 & 10.4 \\
\hline Soybean meal & 8 & 8 & 8 & 8 & 8 & 8 & 8 \\
\hline Fish oil & 6 & 6 & 6 & 6 & 6 & 6 & 6 \\
\hline Vitamin premix & 1 & 1 & 1 & 1 & 1 & 1 & 1 \\
\hline Mineral mixture & 1 & 1 & 1 & 1 & 1 & 1 & 1 \\
\hline Ascorbic acid & 1 & 1 & 1 & 1 & 1 & 1 & 1 \\
\hline Chromic oxide & 1 & 1 & 1 & 1 & 1 & 1 & 1 \\
\hline \multicolumn{8}{|c|}{ Proximate composition of test diets } \\
\hline $\mathrm{CP}(\%)$ & $32.47 \pm 0.18$ & $32.46 \pm 0.14$ & $32.48 \pm 0.11$ & $32.47 \pm 0.15$ & $32.45 \pm 0.15$ & $32.46 \pm 0.12$ & $32.47 \pm 0.16$ \\
\hline EE $(\%)$ & $7.41 \pm 0.03$ & $7.46 \pm 0.14$ & $7.48 \pm 0.11$ & $7.47 \pm 0.15$ & $7.45 \pm 0.15$ & $7.95 \pm 0.04$ & $7.76 \pm 0.20$ \\
\hline GE $\left(\mathrm{kcal} \mathrm{g}^{-1}\right)$ & $3.18 \pm 0.06$ & $3.31 \pm 0.06$ & $3.46 \pm 0.12$ & $3.40 \pm 0.10$ & $3.47 \pm 0.15$ & $3.54 \pm 0.05$ & $3.40 \pm 0.17$ \\
\hline
\end{tabular}


Table 2. Proximate composition (\%) of feed ingredients

\begin{tabular}{|c|c|c|c|c|c|c|}
\hline Ingredients & Dry matter (\%) & Crude protein $(\%)$ & Crude fat $(\%)$ & Crude fibre $(\%)$ & $\operatorname{Ash}(\%)$ & NFE $(\%)$ \\
\hline Fish meal & 91.63 & 48.15 & 7.16 & 1.07 & 25.73 & 17.89 \\
\hline Wheat flour & 92.45 & 10.10 & 2.35 & 2.65 & 2.08 & 82.82 \\
\hline Canola meal & 94.14 & 37.02 & 1.27 & 1.42 & 9.21 & 51.08 \\
\hline Soybean meal & 93.80 & 41.93 & 3.74 & 1.97 & 10.83 & 41.53 \\
\hline
\end{tabular}

extruder (Model SYSLG30-IV Experimental Extruder), to form floating pellets $(3 \mathrm{~mm})$. All diets were equally treated in the given extruder to formulate seven CM-based test diets. All the prepared diets were air dried under a shady place and stored at $4^{\circ} \mathrm{C}$ until use.

\section{Feeding protocol and sample collection}

C. carpio fingerlings were fed with the respective diet at $4 \%$ of the body weight (in two split doses). Feeding session was of $2 \mathrm{~h}$ after which uneaten feed was collected to determine feed conversion ratio (FCR) and water was drained out. The tanks were cleaned and replaced with freshwater. Two hours after completion of the feeding session, faecal matter was collected from each tank using faecal collection tube taking care to prevent breakage to ensure minimum mineral discharge. Faecal matter collected were oven dried at $65^{\circ} \mathrm{C}$ and stored for further analysis.

\section{Growth assessment}

Fifteen fingerlings of initial average weight $(8.07 \pm 0.041 \mathrm{~g})$ were stocked in each replicate tank. Fingerlings from each tank were bulk weighed after every two weeks during the whole experimental period, to assess the growth performance of the fingerlings. FCR, specific growth rate (SGR) and weight gain percentage (WG) of fingerlings were estimated using the following formulae (NRC, 1993):

$$
\begin{array}{ll}
\text { Weight gain } \% & =\frac{(\text { Final weight }- \text { Initial weight })}{\text { Initial weight }} \times 100 \\
\text { FCR } & =\frac{\text { Total dry feed intake }(\mathrm{g})}{\text { Wet weight gain }(\mathrm{g})}
\end{array}
$$$$
\mathrm{SGR} \%=\frac{(\ln . \text { final wt. of fish }-\ln \text {. initial wt. of fish })}{\text { Experimental duration in days }} \times 100
$$

\section{Digestibility studies}

For measurement of apparent digestibility co-efficient (ADC, \%) of nutrients, chromic oxide was used as an inert marker at $1 \%$ inclusion level in test diets. Chromic oxide content in diets and faeces was estimated after oxidation with molybdate reagent using UV-VIS 2001 Spectrophotometer at $370 \mathrm{~nm}$ absorbance (Divakaran et al., 2002). ADC (\%) of nutrients in the diets was calculated using the following formula (NRC, 1993):
$\operatorname{ADC}(\%)=100-100 \times \frac{\% \text { marker in diet } \times \% \text { nutrient in faeces }}{\% \text { marker in faeces } \times \% \text { nutrient in diet }}$

\section{Antioxidant activity}

The effect of polyphenol supplemented diets on antioxidant activity of common carp was determined in terms of percent inhibition of oxidation following Hussain et al. (2011) with slight modification. Fishes sampled from each test group for estimation of antioxidant activity were dried and ground and $1 \mathrm{~g}$ each of the ground sample from each treatment group was taken in a test tube and hexane fraction was prepared, by adding $10 \mathrm{ml}$ of n-hexane in each test tube. Then, this fraction was heated gently in water bath for $10 \mathrm{~min}$. After that, $10 \mathrm{ml}$ solution of $0.2 \mathrm{M}$ was prepared by adding phosphate buffer in each hexane fraction. The test tubes were gently shaken and then $200 \mu 1$ from each test tube was transferred to a new test tube and $200 \mu \mathrm{l}$ of $30 \%$ aqueous ammonium thiocyanate solution was added followed by addition of $200 \mu \mathrm{l}$ of $35 \%$ ferrous chloride solution. Subsequently, $10 \mathrm{ml}$ of $95 \%$ ethanol was added in each test tube and absorbance was measured in a spectrophotometer at $500 \mathrm{~nm}$. The percentage inhibition of oxidation was evaluated using the formula:

Percentage Inhibition of oxidation $(\%)=100 \times($ Absorbance of control sample- Absorbance of test sample/ Absorbance of control sample)

Oxidation $(\%)=100-100 \times($ Absorbance of control sampleAbsorbance of test sample/ Absorbance of control sample)

\section{Statistical analysis}

The data on growth performance and nutrient (crude protein, crude fat and apparent gross energy) digestibility was subjected to one-way analysis ANOVA (Steel et al., 1996). The differences between means were compared and were considered significant at $\mathrm{p}<0.05$ (Snedecor and Cochran, 1991) by Tukey's Honesty Significant Difference Test. For statistical analysis, the Co-Stat computer software (Version 6.303, PMB 320, Monterey, CA, 93940 USA) was used.

\section{Results}

Maximum weight gain (16 g), WG\% (261\%) and SGR $(1.43 \%)$ were recorded in fish fed diet T4 supplemented with $400 \mathrm{mg} \mathrm{kg}^{-1}$ of polyphenol (Table 3) which was 
significantly $(\mathrm{p}<0.05)$ higher compared to weight gain, WG\% and SGR of fish fed control diet. However, in terms of FCR, decreasing trend was observed with increasing levels of polyphenols upto $400 \mathrm{mg} \mathrm{kg}$. Lowest value of FCR (1.31) was observed in fish fed diet T4 having $400 \mathrm{mg}$ of polyphenols per $\mathrm{kg}$ of diet, whereas its value $(1.77 \%)$ was the highest in control diet (T0).

The diets were isocaloric and isonitrogenous (Table 1). The excretion of nutrients from the body of fish was found to be the minimum in fish fed polyphenols supplemented diet. Best level of polyphenol supplementation was found to be $400 \mathrm{mg} \mathrm{kg}$, as excretion of nutrients at this level was the least. From the results of the current study, it was observed that at 400 $\mathrm{mg} \mathrm{kg} \mathrm{kg}^{-1}$ level (diet T4), the digestibility value of crude fat $(76 \%)$ was found to be the highest and significantly different $(\mathrm{p}<0.05)$ from, all other test diets (Table 4). Crude protein $(72 \%)$ and gross energy (67\%), were also found to be highsest for diet T4, which were found to be significantly $(\mathrm{p}<0.05)$ different from other diets, except with test diet T3 (supplemented with $300 \mathrm{mg} \mathrm{kg}^{-1}$ of polyphenol) for crude protein and with test diet T5 (supplemented with $500 \mathrm{mg} \mathrm{kg}^{-1}$ of polyphenol) for gross energy. Lowest digestibility values of nutrients, crude fat $(59 \%)$, crude protein $(56 \%)$ and gross energy (53\%) were noted in fish fed control diet ( $0 \mathrm{mg} \mathrm{kg}^{-1}$ polyphenols).
Table 5 shows the results of antioxidant activity of polyphenols supplemented canola meal based diet in C. carpio. Percentage oxidation in the body of fish was found to decrease with increasing levels of polyphenol supplementation in the diets which indicates increasing antioxidant activity with increasing levels of dietary polyphenols. Test diet T6 supplemented $600 \mathrm{mg} \mathrm{kg}^{-1}$ of polyphenols was found to be the best compared to other test diets as the percentage of oxidation in the body of fish was found to be the lowest (4.25\%) in fish fed diet T6.

\section{Discussion}

Free radicals, that are reactive, are scavenged by antioxidants and protect living cells from oxidative damage (Biglari et al., 2008). Polyphenols are antioxidants in nature and hance are expected to improve antioxidant a ctivity and in turn improves growth performance of fish as well. According to the results of the present study, growth performance of common carp in terms of FCR and weight gain was significantly improved at $400 \mathrm{mg} \mathrm{kg}^{-1}$ level of polyphenols in canola meal based diet. Our findings are in accordance with the results reported by Zhai et al. (2014) who noted lowest FCR (1.31) and improved growth performance in Nile tilapia fed diets supplemented with the antioxidant, grape seed proanthocyanidins (GSP) at levels of 400 and $600 \mathrm{mg} \mathrm{kg}^{-1}$.

Table 3. Growth performance of C. carpio fingerlings fed polyphenols supplemented canola meal based diets

\begin{tabular}{|c|c|c|c|c|c|c|c|}
\hline \multirow{3}{*}{$\begin{array}{l}\text { Growth } \\
\text { parameters }\end{array}$} & Test diet T0 (Control) & Test diet $\mathrm{T} 1$ & Test diet T2 & Test diet T3 & Test diet T4 & Test diet T5 & Test diet T6 \\
\hline & \multicolumn{7}{|c|}{ Polyphenols (mg kg-1) } \\
\hline & 0 & 100 & 200 & 300 & 400 & 500 & 600 \\
\hline IW (g) & $6.17 \pm 0.20^{\mathrm{a}}$ & $6.16 \pm 0.13^{\mathrm{a}}$ & $6.15 \pm 0.11^{\mathrm{a}}$ & $6.14 \pm 0.15^{\mathrm{a}}$ & $6.15 \pm 0.09^{\mathrm{a}}$ & $6.17 \pm 0.09^{\mathrm{a}}$ & $6.16 \pm 0.06^{\mathrm{a}}$ \\
\hline FW (g) & $16.57 \pm 0.71^{\mathrm{c}}$ & $17.09 \pm 0.70^{\mathrm{c}}$ & $17.82 \pm 0.77^{\mathrm{bc}}$ & $19.77 \pm 0.84^{b}$ & $22.23 \pm 0.47^{\mathrm{a}}$ & $19.37 \pm 0.74^{b}$ & $17.27 \pm 0.77^{\mathrm{c}}$ \\
\hline WG (g) & $10.39 \pm 0.52^{\mathrm{e}}$ & $10.92 \pm 0.58^{\mathrm{de}}$ & $11.68 \pm 0.70^{\mathrm{c}}$ & $13.63 \pm 0.95^{\mathrm{bc}}$ & $16.08 \pm 0.39^{\mathrm{a}}$ & $13.20 \pm 0.69^{b}$ & $11.12 \pm 0.72^{\mathrm{b}}$ \\
\hline WG $(\%)$ & $168.30 \pm 3.77^{\mathrm{d}}$ & $177.16 \pm 6.11^{\mathrm{d}}$ & $189.92 \pm 9.50^{\mathrm{cd}}$ & $222.13 \pm 19.41^{b}$ & $261.30 \pm 2.98^{\mathrm{a}}$ & $213.96 \pm 9.66^{b c}$ & $180.50 \pm 10.04^{\mathrm{d}}$ \\
\hline WG $\left(\mathrm{g} \mathrm{day}^{-1}\right)$ & $0.148 \pm 0.007^{\mathrm{d}}$ & $0.156 \pm 0.008^{d}$ & $0.167 \pm 0.010^{\mathrm{cd}}$ & $0.195 \pm 0.014^{\mathrm{b}}$ & $0.230 \pm 0.006^{\mathrm{a}}$ & $0.189 \pm 0.010^{\mathrm{bc}}$ & $0.159 \pm 0.01^{\mathrm{d}}$ \\
\hline FI & $0.26 \pm 0.02^{\mathrm{a}}$ & $0.25 \pm 0.02^{\mathrm{b}}$ & $0.26 \pm 0.03^{\mathrm{a}}$ & $0.28 \pm 0.03^{\mathrm{a}}$ & $0.30 \pm 0.02^{\mathrm{a}}$ & $0.28 \pm 0.02^{\mathrm{a}}$ & $0.27 \pm 0.01^{\mathrm{a}}$ \\
\hline FCR & $1.77 \pm 0.04^{\mathrm{a}}$ & $1.61 \pm 0.01^{\mathrm{abc}}$ & $1.55 \pm 0.10^{\mathrm{abcd}}$ & $1.42 \pm 0.03^{\mathrm{cd}}$ & $1.31 \pm 0.11^{\mathrm{d}}$ & $1.46 \pm 0.04^{\mathrm{bcd}}$ & $1.69 \pm 0.17^{\mathrm{ab}}$ \\
\hline SGR & $1.10 \pm 0.02^{\mathrm{d}}$ & $1.13 \pm 0.02^{\mathrm{d}}$ & $1.18 \pm 0.04^{\mathrm{cd}}$ & $1.30 \pm 0.07^{\mathrm{b}}$ & $1.43 \pm 0.01^{\mathrm{a}}$ & $1.27 \pm 0.03^{\mathrm{bc}}$ & $1.15 \pm 0.04^{\mathrm{d}}$ \\
\hline
\end{tabular}

Means within rows having different superscripts are significantly different $(\mathrm{p}<0.05)$

Data are means of three replicates

$\mathrm{IW}=$ Initial weight, $\mathrm{FW}=$ Final weight, $\mathrm{WG}=$ Weight gain, $\mathrm{FI}=$ Feed intake, $\mathrm{SGR}=$ Specific growth rate, $\mathrm{FCR}=\mathrm{Feed}$ conversion ratio

Table 4. Apparent nutrient digestibility of canola meal based diet with polyphenols supplementation in $C$. carpio fingerlings

\begin{tabular}{|c|c|c|c|c|}
\hline Experimental diets & Polyphenols (mg kg-1) & Crude protein $(\%)$ & Crude fat $(\%)$ & Gross energy $\left(\mathrm{kcal} \mathrm{g}^{-1}\right)$ \\
\hline T0 & 0 & $56.40 \pm 0.79^{\mathrm{e}}$ & $58.50 \pm 0.94^{\mathrm{d}}$ & $52.93 \pm 0.98^{\mathrm{e}}$ \\
\hline $\mathrm{T} 1$ & 100 & $59.63 \pm 0.93^{\mathrm{d}}$ & $55.63 \pm 0.77^{\mathrm{e}}$ & $53.49 \pm 0.75^{\mathrm{e}}$ \\
\hline $\mathrm{T} 2$ & 200 & $64.87 \pm 0.80^{\mathrm{c}}$ & $63.26 \pm 0.94^{\mathrm{c}}$ & $59.76 \pm 0.97^{\mathrm{c}}$ \\
\hline $\mathrm{T} 3$ & 300 & $70.59 \pm 0.82^{\mathrm{a}}$ & $72.41 \pm 0.74^{b}$ & $63.40 \pm 0.95^{\mathrm{b}}$ \\
\hline $\mathrm{T} 4$ & 400 & $72.36 \pm 0.90^{\mathrm{a}}$ & $76.38 \pm 0.73^{\mathrm{a}}$ & $66.59 \pm 0.71^{\mathrm{a}}$ \\
\hline T5 & 500 & $67.72 \pm 0.85^{b}$ & $71.27 \pm 0.92^{b}$ & $66.36 \pm 0.75^{\mathrm{a}}$ \\
\hline T6 & 600 & $59.72 \pm 0.97^{d}$ & $63.18 \pm 0.53^{\mathrm{c}}$ & $56.65 \pm 0.86^{\mathrm{d}}$ \\
\hline
\end{tabular}

Means within rows having different superscripts are significantly different $(p<0.05)$

Data are means of three replicates 
Table 5. Antioxidant activity of polyphenols supplemented canola meal based diet

\begin{tabular}{lll}
\hline $\begin{array}{l}\text { Concentration of } \\
\text { polyphenol }\left(\mathrm{mg} \mathrm{kg}^{-1}\right)\end{array}$ & Absorbance & Oxidation (\%) \\
\hline $0(\mathrm{~T} 0)$ & $0.0282 \pm 0.00010$ & $100.00 \pm 0.00$ \\
$100(\mathrm{~T} 1)$ & $0.0273 \pm 0.00010$ & $96.81 \pm 0.35$ \\
$200(\mathrm{~T} 2)$ & $0.0266 \pm 0.00021$ & $94.44 \pm 0.73$ \\
$300(\mathrm{~T} 3)$ & $0.0243 \pm 0.00015$ & $86.29 \pm 0.84$ \\
$400(\mathrm{~T} 4)$ & $0.0065 \pm 0.00021$ & $23.17 \pm 0.82$ \\
$500(\mathrm{~T} 5)$ & $0.0046 \pm 0.00015$ & $16.19 \pm 0.56$ \\
$600(\mathrm{~T} 6)$ & $0.0012 \pm 0.00010$ & $4.25 \pm 0.35$ \\
\hline
\end{tabular}

Shin et al. (2010a, b) when fed olive flounder Paralichthys olivaceus on diet containing 250 or $500 \mathrm{mg} \mathrm{kg}^{-1}$ quercetin (dietary polyphenolic compound) for 30 and 60 days, observed weight gain to be significantly higher than that of fish fed on control diet. Shin et al. (2010a) also observed that administration of quercetin in diet improved FCR in olive flounder. Significant increase in the SGR rate as well as weight gain of $O$. niloticus was observed when 2400 $\mathrm{mg} \mathrm{kg}^{-1}$ of structural analogue of quercitin, Dihydromyricetin was included in feed (Cai et al., 2010). Spirulina, being rich in polyphenols, has been used by many researchers and positive effects of spirulina are reported on the growth of fish species, including small scale black fish (Nakazoe et al., 1986); red seabream (Mustafa et al., 1994); rohu (Nandeesha et al., 2001); Siberian sturgeon (Palmegiano et al., 2005) and Nile tilapia (Lu et al., 2004; AbdelTawwab et al., 2010). Tongsiri et al. (2010) replaced 5\% of fish meal with spirulina and reported better growth performance in Pangasianodon gigas. Pham et al. (2006) reported that with the increase in supplementation levels of Hizikia fusiformis (another potent source of polyphenols); in the diet, the growth of olive flounder improved, which showed that its supplementation has positive effect on growth of fish. Fallahpour (2015) observed significant improvement in weight gain in commmon carp fed on diet supplemented with marshmallow (Althaea officinalis) extract $(0.25 \%)$. Jian and $\mathrm{Wu}(2004)$ reported higher weight gain in carp when diet was supplemented with a mixture of Chinese angelica root and astragalus root as sources of polyphenols. Munglue (2014) found growth performance to be significantly better in Nile tilapia (Oreochromis niloticus) fed with $1 \%$ Nelumbo nucifera (Lotus) peduncle extract (NNPE), rich in polyphenols.

A wide range of biological activities, are shown by polyphenols (Kamatou et al., 2010; Samec et al., 2010), including health-promoting effects (Biglari et al., 2008). Recent studies have also shown that polyphenolic compounds possess protective effects on immune system (Aquilano et al., 2008; Franova et al., 2010). The results of our study clearly showed that increased dietary polyphenol level was positively correlated with antioxidant capacity of the diets. The highest antioxidant activity was observed in $600 \mathrm{mg} \mathrm{kg}^{-1}$ of polyphenols supplemented diet group, whereas least was noted in fish fed control diet. Our findings are in accordance with the results of study by Shin et al. (2010) who reported that inclusion of quercetin, a polyphenol, in diet of olive flounder gave positive results. They found lower cholesterol levels and increased levels of superoxide dimutase and catalase (both are antioxidant enzymes) which is a good sign in inhibiting oxidation. Zheng et al. (2009) treated channel catfish with antioxidant oregano and reported increased activity of plasma lysozyme. Tang et al. (2001) added tea catechins in muscle patties of fish and observed that the prooxidative effect of $\mathrm{NaCl}$ was significantly $(p<0.01)$ inhibited at level of $300 \mathrm{mg} \mathrm{kg}^{-1}$ of minced muscle and controlled lipid oxidation in all cooked muscle patties. Amer (2016) reported that by feeding dietary S. platensis (rich polyphenols source) to Nile tilapia (monosex), catalase activity was found to be increased along with glutathione reductase and formation of malondialdehyde reduced, which is secondary product formed during peroxidation of lipids. Ragap et al. (2012) reported that lysozyme activity was maximum in Nile tilapia fed on diet supplemented with spirulina ( $10 \mathrm{mg} \mathrm{kg}^{-1}$ fish) in comparison to fish fed diet supplemented withspirulina at $1 \mathrm{mg} \mathrm{kg}^{-1}$ fish and fish fed control diet. Similarly, Ibrahem et al. (2013) also reported that spirulina supplementation in diet upto $10 \%$, improved level of lysozyme in Nile tilapia.

El-Mesallamy et al. (2016) observed that inclusion of dried flowers of Hibiscus sabdariffa (source of polyphenols) in the diet of Nile tilapia enhanced immune/ health status; and improved disease resistance as well as growth performance. Darsini et al. (2013) supplemented Limonia acidissima fruit, in diet of common carp and reported that superoxide dismutase (SOD) activity in liver, muscle homogenates and serum, significantly increased in fish groups fed with the experimental diets as compared to control diet. Similarly, Papuc et al. (2012) incorporated polyphenols from sea buckthorn fruits in the minced carp muscles, at levels of $250 \mathrm{mg} \mathrm{kg}^{-1}$ and reported that it aided in inhibiting oxidation of lipids and proteins in all types of carp muscle. The role of polyphenols in enhancing antioxidant activity is clearly evident from all these studies. Higher digestibility values of crude fat $(64 \%)$, crude protein $(76 \%)$ and gross energy $(66 \%)$ were also reported for test diet supplemented with $400 \mathrm{mg} \mathrm{kg}^{-1}$ polyphenols. Many reports have appreciated the use of polyphenols for improving the digestibility of nutrients. Fallahpour et al. (2015) attributed the improvement in growth of fish fed diet supplemented with marshmallow extract to the influence of marshmallow on improving the nutrient digestibility, increasing the efficiency of nutrient absorption and feed utilisation. Adamidou et al. 
(2009) found that incorporation of 150 and $300 \mathrm{~g} \mathrm{~kg}^{-1}$ faba bean in extruded diets for juveniles of European seabass significantly improved the ADC for protein, fat and energy as compared to the control diet.

However, contradictory results have also been reported. Omnes et al. (2017) observed inverse dose response relationship between dietary tannin level and ADC for dry matter (DM) as well as energy in European seabass, while positive correlation was observed between tannin level and ADC for protein. Tannins from a Fabaceae plant extract at levels equal to or greater than $6.3 \mathrm{~g} \mathrm{~kg}^{-1}$ also significantly affected $\mathrm{DM}$ and protein digestibility in Nile tilapia (Pinto et al., 2000). Frejnagel and Wroblewska (2010) reported that supplementation of extracts of polyphenols resulted in significant reduction of absorption of all measured nutrients from the intestine of monogastric animals. Differences between the results of the present study with the above findings could be attributed to the difference in species, nutrients need, their feeding condition and levels of dietary polyphenols (Zhai et al., 2013).

Our study clearly showed that polyphenols are potent source of antioxidants and they have significant positive impact on growth and digestibility of nutrients in fish at a dietary level of $400 \mathrm{mg} \mathrm{kg}^{-1}$. Increased levels of supplementation of polyphenols in diet aided in reduced oxidation indicating improved antioxidant activity. Hence, canola meal along with supplementation of polyphenols ensures productively effective and affordable fish diet which is more likely to produce healthy fish and overcome the issue of ever increasing cost of fish meal that is expected to escalate in future.

\section{References}

Abdel-Tawwab, M., Ahmad, M. H., Seden, M. E. and Sakr, S. F. 2010. Use of green tea, Camellia sinensis L. in practical diet for growth and protection of nile tilapia, Oreochromis niloticus (L.), against Aeromonas hydrophila infection. J. World Aquac. Soc., 41(2): 203-213. doi.org/10.1111/j. 1749-7345.2010.00360.x.

Adamidou, S., Nengas, I., Alexis, M., Foundoulaki, E., Nikolopoulou, D., Campbell, P., Karacostas, I., Rigos, G., Bell, G. J. and Jauncey, K. 2009. Apparent nutrient digestibility and gastrointestinal evacuation time in European seabass (Dicentrarchus labrax) fed diets containing different levels of legumes. Aquaculture, 289(1): 106-112.

Allan, G. L. and Rowland, S. J. 1992. Development of an experimental diet for silver perch (Bidyanus bidyanus). Australian Aquac., 6: 39-40.

Amer, S. A. 2016. Effect of Spirulina platensis as feed supplement on growth performance, immune response and antioxidant status of mono-sex nile tilapia (Oreochromis niloticus). Benha Vet. Med. J., 30(1): 1-10. DOI: 10.21608/ bvmj.2016.31332.

AOAC 1995. Official methods of analysis, $15^{\text {th }}$ edn. Association of Official Analytical Chemists, Washington D.C., USA, $1094 \mathrm{pp}$.

Aquilano, K., Baldelli, S., Rotilio, G. and Ciriolo, M. R. 2008. Role of nitric oxide synthases in Parkinson's disease: a review on the antioxidant and anti-inflammatory activity of polyphenols. Neur. Res., 33(12): 2416-2426. DOI: 10.1007/s11064-008-9697-6

Biglari, F., AlKarkhi, A. F. and Easa, A. M. 2008. Antioxidant activity and phenolic content of various date palm (Phoenix dactylifera) fruits from Iran. Food Chem., 107(4): 1636-1641. DOI: 10.1016/j.foodchem.2007.10.033.

Cai, Y. H., Zhang, S. X. and Zhang, L. 2010. Effects of dihydromyricetin on the growth, immunity and antioxidant function of tilapia. Guang. Feed, 19: 19-21.

Darsini, D. T. P., Maheshu, V., Srinivasan, P., Nishaa, S. and Castro, J. 2013. Dietary supplementation of Limonia acidissima $\mathrm{L}$. fruit on in vivo antioxidant activity and lipid peroxidation of Cyprinus carpio. Int. Conf. Sust. Env. Agric., 57(14): 73-79. DOI: 10.7763/IPCBEE. 2013. V57. 14.

Divakaran, S., Leonard, G. O. and Ian, P. F. 2002. Note on the methods for determination of chromic oxide in shrimp feeds. J. Agric. Food Chem., 50: 464-467. doi.org/10.1021/ jf011112s.

El-Mesallamy, A. M., Ahmad, M. H., Souleman, A. M., El-Morsy, A.T. and El-Naby, A. S. A. 2016. Effects of roselle calyx (Hibiscus sabdariffa L.) supplemented diets on growth and disease (Aeromonas hydrophila) resistance in Nile tilapia (Oreochromis niloticus L.). Egyp. Pharma. J., 15(2): 78-87. DOI: 10.4103/1687-4315.190403.

Enami, H. R. 2011. A review of using canola rapeseed meal in aquaculture feeding. J. Fish. Aquac. Sci., 6(1): 22-36. DOI: $10.3923 /$ jfas.2011.22.36.

Fallahpour, F., Banaee, M. and Javadzade, N. 2015. The effects of hydro-alcohol extract of follower of marshmallow (Althaea officinalis L.) on some biochemical and hematological parameters in common carp (Cyprinus carpio). J. Herb. Drugs (An Int. J. Medi. Herbs), 6(2): 73-83.

Fasakin, E. A. 2007. Fish as food yesterday, today and forever, inaugural lecture. The Federal University of Technology, Akure, 48: 52-63.

Franova, S., Joskova, M., Sutovska, M., Novakova, E., Adamicova, K., Pechanova, O. and Nosalova, G. 2010. The efficiency of polyphenolic compounds on allergen induced hyper reactivity of the airways. Biomed. Prev. Nutr., 1(4): 232-235.

Frejnagel, S. and Wroblewska, M. 2010. Comparative effect of green tea, chokeberry and honeysuckle polyphenols on nutrients and mineral absorption and digestibility in rats. Ann. Nutr. Met., 56(3): 163-169. doi: 10.1159/000278747. 
Gabor, E. F., Sara, A., Bentea, M., Creta, C. and Baciu, A. 2012. The effect of phytoadditive combination and growth performances and meat quality in rainbow trout (Oncorhychus mykiss). Sci. Pap. Anim. Sci. Biotech., 45(2): 43-47.

Gabriel, U. U., Akinrotimi, O. A., Bekibele, D. O., Onunkwo, D. N. and Anyanwu, P. E. 2007. Locally produced fish feed -potentials for aquaculture development in sub-Saharan Africa. Afr. J. Agric. Res., 2(7): 287-295.

Ghasemi, K., Ghasemi, Y. and Ebrahimzadeh, M. A. 2009. Antioxidant activity, phenol and flavonoid contents of 13 citrus species peels and tissues. Pak. J. Pharm. Sci., 22(3): 277-281.

Hussain S. M., Afzal, M., Nasir, S., Javid, A., Azmat, H., Makhdoom, S. M., Shah, S. Z. H., Hussain, M., Mustafa, I. and Iqbal, M. 2015. Role of phytase supplementation in improving nutrient digestibility and growth performance of Labeo rohita fingerlings fed on canola meal-based diet. J. Appl. Anim Res., 45(1): 15-21. doi.org/10.1080/097121 19.2015.1091331.

Hussain, A. I., Anwar, F., Iqbal, T. and Bhatti, I. A. 2011. Antioxidant attributes of four Lamiaceae essential oils. Pak. J. Bot., 43(2): 1315-1321.

Ibrahem, M. D., Mohamed, M. F. and Ibrahim, M. A. 2013. The role of Spirulina platensis (Arthrospira platensis) in growth and immunity of Nile tilapia (Oreochromis niloticus) and its resistance to bacterial infection. J. Agric. Sci., 5(6): 109-117.

Jian, J. and $\mathrm{Wu}, \mathrm{Z}$. 2004. Influence of traditional Chinese medicine on non-specific immunity of Jian carp (Cyprinus carpio var. jian). Fish Shell. Immunol., 16(2): 185-191. DOI: 10.1016/S1050-4648(03)00062-7.

Kamatou, G. P., Viljoen, A. M. and Steenkamp, P. 2010. Antioxidant, anti-inflammatory activities and HPLC analysis of South African salvia species. Food Chem., 119(2): 684-688.

Kazimierczak, R., Hallmann, E., Rusaczonek, A. and Rembialkowska, E. 2008. Antioxidant contents in black currants from organic and conventional cultivation. Electronic J. Polish Agric. Univ., 11(2): 28-33.

Khan, M. N., Shahzad, K., Chatta, A., Sohail, M., Piria, M. and Treer, T. 2016. A review of introduction of common carp Cyprinus carpio in Pakistan: origin, purpose, impact and management. Croatian J. Fish., 74(2): 71-80. DOI: 10.1515/cjf-2016-0016.

Lovell, R. T. 1989. Nutrition and feeding of fish. Van NostrandReinhold, New York, 260 pp.

Lu, J., Takeuchi, T. and Satoh, H. 2004. Ingestion and assimilation of three species of freshwater algae by larval tilapia Oreochromis niloticus. Aquaculture, 238(1): 437-449. DOI: 10.1016/j.aquaculture.2004.05.002.

Mahboob, S. 2014. Replacing fish meal with a blend of alternative plant proteins and its effect on the growth performance of Catla catla and Hypophthalmichthys molitrix. Pak. J. Zool., 46(3): 747-752.
Medina, I., Gallardo, J. M. and Aubourg, S. P. 2009. Quality preservation in chilled and frozen fish products by employment of slurry ice and natural antioxidants. Int. J. Food Sci. Tech., 44(8): 1467-1479. DOI: 10.1111/j.13652621.2009.02016.x.

Mustafa, M. G., Umino, T. and Nakagawa, H. 1994. The effect of spirulina feeding on muscle protein deposition in red seabream, Pagrus major. J. Appl. Ichthyol., 10: 141-145. https://doi.org/10.1111/j.1439-0426.1994.tb00153.x.

Nakazoe, J. I., Kimura, S., Yokoyama, M. and Iida, H. 1986. Effects of the supplementation of algae or lipids to the diets on the growth and body composition of nibbler Girella punctata. Bull. Tokai Reg. Fish. Res. Lab., 120: 43-51.

Nandeesha, M. C., Gangadhara, B., Manissery, J. K. and Venkataraman, L. V. 2001. Growth performance of two Indian major carps, catla (Catla catla) and rohu (Labeo rohita) fed diets containing different levels of Spirulina platensis. Biores. Tech., 80(2): 117-120. DOI: 10.1016/ s0960-8524(01)00085-2.

NRC 1993. Nutrient requirements of fish. National Research Council, National Academy Press, Washington, DC, USA, p. 233-289.

NRC 2011. Nutrient requirements of fish and shrimp. National Research Council, National Academies Press, Washington, D. C., USA, p. 624-642.

Omnes, M. H., Le, G. J., Le, D. H., Le, B. N., Quazuguel, P. and Robin, J. H. 2017. Effects of dietary tannin on growth, feed utilisation and digestibility, and carcass composition in juvenile European seabass (Dicentrarchus labrax L.). Aquac. Rep., 6: 21-27.

Palmegiano, G. B., Agradi, E., Forneris, G., Gai, F., Gasco, L., Rigamonti, E., Sicuro, B. and Zoccarato, I. 2005. Spirulina as a nutrient source in diets for growing sturgeon (Acipenser baeri). Aquac. Res., 36(2): 188-195.

Papuc,C.,Crivineanu,M.,Nicorescu,V.,Papuc,C.andPredescu,C. 2012. Increase of the stability to oxidation of lipids and proteins in carp muscle (Cyprinus carpio) subject to storage by freezing by polyphenols extracted from Sea buckthorn fruits (Hippophae rhamnoides). Revista de Chimie, 63(12): 1198-1203.

Pham, M. A., Lee, K., Lee, B., Lim, S., Kim, S., Lee, Y. and Lee, K. 2006. Effects of dietary Hizikia fusiformis on growth and immune responses in juvenile olive flounder (Paralichthys olivaceus). Asian Aus. J. Anim. Sci., 19(12): 1769-1775.

Pinto, L. G. Q., Pezzato, L. E., Miranda, E. C., Barros, M. M. and Furuya, W. M. 2000. Action of tannin on digestibility of diets by Nile tilapia (Oreochromis niloticus). Acta Scient. Anim. Sci., 22(1): 677-681 (In Portuguese).

Ragap, H. M., Khalil, R. H. and Mutawie, H. H. 2012. Immunostimulant effects of dietary Spirulina platensis on tilapia Oreochromis niloticus. J. Appl. Pharm. Sci., 2(2): 26-31. 
Rechulicz, J., Katarzyna, O. K. and Grela, E. R. 2014. The effect of adding protein-xanthophylls concentrate (PX) from lucerne (Medicago sativa) on growth parameters and redox profile in muscles of carp, Cyprinus carpio (L.). Turk. J. Fish. Aquat. Sci., 14(3): 697-703. DOI: 10.4194/13032712-v14_3_12.

Rowland, S. J. and Ingram, B. A. 1991. Diseases of Australian native fishes. Fisheries Bulletin 4 NSW Fisheries, Sydney, New South Wales, Australia.

Samec, D., Gruz, J., Strnad, M., Kremer, D., Kosalec, I., Grubesic, R. J., Karlovic, K., Lucic, A. and Piljac-Zegarac, J. 2010. Antioxidant and antimicrobial properties of Teucrium arduini L. (Lamiaceae) flower and leaf infusions (Teucrium arduini L. antioxidant capacity). Food Chem. Toxicol.: An Int. J. Pub Brit. Ind. Biol. Res. Ass., 48(1): 113-119.

Sampels, S. 2013. Oxidation and antioxidants in fish and meat from farm to fork. Food Industry, p 115-144. DOI: $10.5772 / 55834$

Shin, H. S., Yoo, J. H., Min, T. S., Lee, J. and Choi, C. Y. 2010a. The effects of quercetin on physiological characteristics and oxidative stress resistance in olive flounder, Paralichthys olivaceus. Asian Austral. J. Anim., 23: 588-597. DOI: https://doi.org/10.5713/ajas.2010.90624.

Shin, H. S., Yoo, J. H., Min, T. S., Lee, J. and Choi, C. Y. 2010 b. Effect of quercetin on the activity and mRNA expression of antioxidant enzymes and physiological responses in olive flounder (Paralichthys olivaceus) exposed to cadmium. Asian Austral. J. Anim., 23: 742-749. DOI: https://doi. org/10.5713/ajas.2010.10006.

Snedecor, G. W. and Cochran, W. G. 1991. Statistical methods. $8^{\text {th }}$ edn. Iowa State University Press, Ames, Iowa, USA, 503 pp.
Steel, R. G. and Torrie, J. H. 1996. Principles and procedures of statistics, $3^{\text {rd }}$ edn. McGraw Hill International Book Co. Inc.,. New York, USA, p 336-352.

Tang, S., Kerry, J. P., Sheehan, D., Buckley, D. J. and Morrissey, P. A. 2001. Antioxidative effect of added tea catechins on susceptibility of cooked red meat, poultry and fish patties to lipid oxidation. Food Res. Int., 34(8): 651-657. DOI: 10.1016/s0963-9969(00)00190-3.

Tongsiri, S., Mang-Amphan, K. and Peerapornpisal, Y. 2010. Effect of replacing fishmeal with spirulina on growth, carcass composition and pigment of the Mekong giant catfish. As. J. Agric. Sci., 2(3): 106-110.

Zhai, S. W. and Liu. S. L. 2013. Effects of dietary quercetin on growth performance, serum lipids level and body composition of tilapia (Oreochromis niloticus). Ital. J. Anim. Sci., 12(85): 523-527. https://doi.org/10.4081/ijas. 2013.e85.

Zhai, S. W., Lu, J. J. and Chen, Z. H. 2014. Effects of dietary grape seed proanthocyanidins on growth performance, some serum biochemical parameters and body composition of tilapia (Oreochromis niloticus) fingerlings. Ital. J. Anim. Sci., 13(3): 536-540. https://doi.org/10.4081/ ijas.2014.3357.

Zheng, Z. L., Tan, J. Y., Liu, H. Y., Zhou, X. H., Xiang, X. and Wang, K. Y. 2009. Evaluation of oregano essential oil (Origanum heracleoticum L.) on growth, antioxidant effect and resistance against Aeromonas hydrophila in channel catfish (Ictalurus punctatus). Aquaculture, 292(3): 214-218. 